\title{
Impact of Air-Flow Rate and Biochar Addition on the Oxygen Concentration in Waste and Emitted Gases During Biostabilization of Undersized Fraction from Municipal Solid Waste
}

\author{
Mateusz Malinowski ${ }^{*}$ \\ 1 Department of Bioprocesses Engineering, Energetics and Automatization, University of Agriculture in \\ Krakow, ul. Balicka 116b, 30-149 Kraków, Poland \\ * Corresponding author's e-mail: mateusz.malinowski@urk.edu.pl
}

\begin{abstract}
Mechanical biological treatment of waste is still one of the most popular methods for mixed municipal waste treatment. The result of mechanical processing of waste is sorting out: the undersized fraction from municipal solid waste (UFMSW) with granulation below $80 \mathrm{~mm}$, rich in biodegradable organic waste (mainly including food waste, paper, wood, etc.). UFMSW is treated in biological processes in order to reduce the negative environmental effect of this waste. Unfortunately, the processing is not neutral to the environment. The correct course of the aerobic biostabilization process depends on the activity of microorganisms, the intensity of aeration, and the oxygen content in the processed waste. The aim of this paper was to analyze the effect of air-flow rate and biochar addition on the oxygen concentration in waste and in emitted gases during the intensive phase of UFMSW biostabilization. The study was performed under laboratory conditions. Six different variants of the process (without biochar addition and using $1.5 ; 3 ; 5 ; 10$ and $20 \%$ of biochar addition) were applied. Subsequent replicates were conducted using an averaged air-flow rate of $0.1,0.2$, and $0.4 \mathrm{~m}^{3} \mathrm{~d}^{-1} \mathrm{~kg} \mathrm{dm} . \mathrm{org}^{-1}$. As a result of the conducted experiments, it was found that both the air-flow rate and the addition of biochar have a significant effect on the oxygen concentration in the treatment waste, as well as its content in the outlet air. Using the highest air-flow rate resulted in the oxygen content not decreasing below $14 \%$, both in the free spaces between the waste and in the emitted gases, while the addition of biochar significantly reduced the oxygen concentration. In the case of lower air-flow rate values, the oxygen content decreased even below 5\%. It was found that a high addition of biochar (10 and 20\% by weight) at the lowest air-flow rate resulted in the occurrence of anaerobic zones in waste in the first days of the intensive process (between days 2 and 6 of the process), as well as absence of oxygen in the outlet air (between days 2 and 4 of the process). Despite this, no methane (biogas) emissions were found in any of the conducted experiments.
\end{abstract}

Keywords: municipal solid waste, biochar, intensive phase of biostabilization, oxygen concentration

\section{INTRODUCTION}

A large mass of municipal solid waste (MSW) is still generated in many countries of the world, where the idea of preventing or minimizing waste in accordance with the circular economy is only just being developed. These wastes are mainly managed in mechanical-biological treatment (MBT) plants (De Gisi et al., 2018; Soboniak and Bień, 2015), where the undersized fraction from municipal solid waste (UFMSW) with a granulation below $80 \mathrm{~mm}$ is separated mechanically (Dziedzic, el al., 2015). Due to the low efficiency of selective collection of organic waste (food waste, wood, paper, etc.) in households, a large share of biodegradable waste goes to MSW (Stejskal et al., 2017; Voytovych et al., 2020) and then to UFMSW. As reported by Baran et al. (2016), Dębicka et al. (2017), or Malinowski et al. (2021), the share of biodegradable waste in UFMSW is about $40 \mathrm{wt} \%$. Having considered the foregoing, UFMSW is suitable for processing using biological methods, mainly aimed at limited stabilization of their microbiological activity (Kasiński et al., 2016; Jędrczak and Suchowska-Kisielewicz, 2018). Reaching thermophilic temperature 
(above $45^{\circ} \mathrm{C}$ ) in the bioreactor over time should enable limited, but sufficient sanitation of the waste (Jakubowski, 2019).

Aerobic biostabilization is the most popular treatment process for UFMSW (De Gisi et al., 2018). The purpose of this process is to reduce the volume and mass of UFMSW, decrease respiration activity (AT4), microbial activity, carbon and organic matter (OM) content and, as a result, reduce the potential biogas emissions from landfills, where the waste ultimately ends up (Velis et al., 2009; Jędrczak and Suchowska-Kisielewicz, 2018). This process can be carried out in special bioreactors in a one- or two-stage system. Most of the time, the waste stays for at least 2 weeks in thermally isolated and aerated bioreactors (intensive phase), followed by a maturation phase of 6-12 weeks in open windrows (Dziedzic et al., 2015; den Boer and Jędrczak, 2017; Vaverková et al., 2020).

Grzesik and Malinowski (2017) found that the biostabilization has a very negative effect on the environment due to odor emissions, leachate generation and final waste deposition to landfills. In addition, the gases emitted in the biological treatment of waste have to be purified (Białowiec, 2018). Various deodorization methods are used for this purpose (Grzelka et al., 2018; Pawnuk et al., 2020): absorption, adsorption, biological methods, combustion, condensation, encapsulation, and masking. Biofilters (special devices filled with bark, sawdust and woodchips, as well as other similar biological material) are most often used in the existing MBT installations, with greatly varying efficiency ranging from 20 to $99.9 \%$, depending on the type of pollutant removed (Grzelka et al., 2018). This indicates a great need to address this problem in order to find new methods of waste aerobic biostabilization that do not create an environmental burden. The current scientific research in the field of UFMSW biostabilization is mainly focused on eliminating the odors from this process in order to achieve the requirements set by Best Available Techniques (BAT) conclusions on waste treatment issued by the European Commission (BAT, 2018).

Correctly selected aeration is a key factor affecting the correct course of the biostabilization process as well as the reduction of greenhouse gas and odor emissions (Puyuelo et al., 2014). Aeration leads to the removal of excess moisture and excess heat from the process (Knapczyk et al., 2019). Oxygen is essential for the microorganisms responsible for the normal course of aerobic biostabilization (Jędrczak, 2008; Czekała et al., 2015). Oxygen level in treated waste is also a critical parameter on the gaseous emissions of $\mathrm{CO}_{2}, \mathrm{NH}_{3}, \mathrm{~N}_{2} \mathrm{O}, \mathrm{H}_{2} \mathrm{~S}, \mathrm{CH}_{4}$ and Volatile Organic Compounds (Puyuelo et al., 2014; Baran et al., 2016; Białowiec, 2018). The highest concentrations of the emitted gases and their emissions are observed when the highest temperatures of the treated waste are reached (Baran, et al. 2016). This is due to, among other things, the high activity of microorganisms responsible for the decomposition of the organic matter contained in waste (Jedrczak, 2008).

The correct selection of the air-flow rate should prevent the formation of anaerobic zones in treated waste, which pose a real threat to the health and life of workers operating the biostabilization process in the long term. The correct oxygen concentration in the free spaces of processed waste should be between 12 and $21 \%$ (optimum range $>15 \%$ ) (Jędrczak, 2008). Aerobic microorganisms die without sufficient oxygen supplied to the process, and their place is taken by anaerobic microorganisms. This happens when the oxygen content in the free spaces inside the waste decreases below 5\% (Jedrczak, 2008).

Another way to optimize the greenhouse gas (GHG) emissions from the process is to prepare optimal compositions of the mixtures for biological processing, e.g. by adding natural structural materials, the so-called bulking agents (Malińska and Zabochnicka-Świątek, 2013; Tom et al. 2016; Neugebauer and Sołowiej 2017), sawdust (Maxianová and Vaverková, 2021), mineral sorbents (Wierzbińska, 2021) or digestate (Malinowski et al. 2021). The applied additives are designed to change the $\mathrm{C} / \mathrm{N}$ ratio, bulk density (BD) and air-filled porosity (AFP) of the treated waste, which should result in a better oxygen distribution and prevent the formation of anaerobic zones in the treated waste. There is no agreement in the literature on the optimal AFP porosity during composting (Janczak et al., 2017). Michel et al. (2004) pointed out that air-filled porosity of over $75 \%$ prevented thermophilic temperatures from being achieved. However, Ahn et al. (2008) reported that the optimal porosity for aerobic decomposition was $85-90 \%$. No such analyses were conducted for the biostabilization process.

One of the additives successfully used in the composting process of the organic fraction of MSW is biochar (Malinowski et al. 2019). 
Biochar is a carbon-rich material, obtained in an oxygen-limited environment (Akdeniz, 2019). This substance is characterized by elevated specific surface area, high porosity and water retention capacity (Khan et al. 2014). It is produced from biomass and organic waste. Biochar is stable in terms of chemical composition and does not show susceptibility to degradation or biological decomposition. The main advantages of using biochar in biological treatment of waste include the accumulation of water and nitrogen in the resulting product, as well as the reduction of greenhouse gas emissions and faster decomposition of biodegradable parts of waste in the intensive phase of the composting process (Agyarko-Mintah et al., 2017a; 2017b; Malinowski et al., 2019). This may be related to the physical and physicochemical properties of biochar, such as its specific surface area, carbonaceous functional groups, and optimum pore volume (Godlewska et al., 2017).

In this paper, the author made an attempt to find an answer to the question of how the addition of biochar affects the oxygen concentration in processed UFMSW and in outlet air (emitted gases) during the intensive phase of the aerobic biostabilization process. There are several scientific papers about the effect of aeration on the processing of green waste and food waste in the composting process (Scaglia et al., 2011; Puyuelo et al., 2014; Kasiński et al., 2016), but to the best of the author's knowledge, the effect of adding biochar to aerobic biostabilization process has not been investigated.

The author hypothesized that biostabilization of UFMSW with biochar would have a positive effect on the oxygen concentration in the free spaces between treated wastes and in the process gases directed to the biofilter. Moreover, this effect could be modified by the specific content of biochar applied and the air-flow rate.

The aim of this study was to assess whether, the application of biochar at six various doses affects the course of the biostabilization process (3-week intensive phase) conducted under laboratory conditions and if so, then to what extent. The evaluation included changes in temperature and oxygen concentration in the free spaces between the treated wastes and in the process gases directed to the biofilter. The changes in bulk density (BD) and air-filled porosity are also described in the paper. The main novelty of this research consists in studying the effect of biochar addition on the biostabilization process (3-week intensive phase) of UFMSW.

\section{MATERIAL AND METHODS}

The biostabilization process is technologically similar to the composting of food waste, but it results in waste called stabilized waste, rather than compost (fertilizer). The process involves the microorganisms contained in waste, which maintain activity and process organic matter as a result of air flow and release thermal energy in the course of enzymatic reactions (Malinowski et al., 2021). The tests were performed using insulated BKB 100 laboratory bioreactor (ROTAMETR, Gliwice, Poland) with a working volume of $116 \mathrm{dm}^{3}$ and a working height of $99 \mathrm{~cm}$. Its working principle was described in detail by Baran et al. (2016) and Malinowski et al. (2021). The conducted study was focused on the intensive phase of aerobic biostabilization. The analyzed time for each mixture was the first 21 days (intensive phase). The tests were carried out under laboratory conditions at a stable temperature (19.6 \pm $1.0^{\circ} \mathrm{C}$ ). The temperature of the waste received for the process was $14.4 \pm 2.1^{\circ} \mathrm{C}$.

The waste samples used in this research consisted of UFMSW produced during the process of mechanical treatment (MSW treatment on $80 \mathrm{~mm}$ trommel screen) in an MBT plant (MIKI Recykling Ltd.) in Kraków (Poland) $(50.032445247 \mathrm{~N}, 20.061035156 \mathrm{E})$. Biochar was produced in Poland from wood chips by using the pyrolysis process at $550^{\circ} \mathrm{C}$. It was obtained in the Thermalization Energy Recovery Module (Malinowski et al. 2019). The biochar used in this study contained over $80 \%$ of $\mathrm{C}$, was characterized by high AFP (over $85 \%$ ) and low $\mathrm{pH}$, low moisture content and bulk density. Its physicochemical characterization was very similar to that reported by Malinowski et al. (2019). Six different doses of biochar were applied in the process: B1.5\%, $\mathrm{B} 3 \%, \mathrm{~B} 5 \%, \mathrm{~B} 10 \%, \mathrm{~B} 20 \%$ and $\mathrm{B} 0 \%$ without the addition of biochar as a control sample ( $\%$ are expressed as wet weight).

For each biochar addition, repeated biostabilization processes were conducted at different average air-flow rates $\left(0.1 ; 0.2\right.$ and $0.4 \mathrm{~m}^{3}$ of air per kg of d.m.org per 24h). The intensity of aeration was controlled as a function of waste temperature. The temperature was prevented from exceeding $65^{\circ} \mathrm{C}$ during the process. The air-flow rates used in the experiment were selected based on the results of Tom et al. (2016), Yuan et al. (2017) and Neugebauer et al. (2018). The initial mass of waste placed in the bioreactor was 
$50.5 \pm 3.8 \mathrm{~kg}$. Leachate and scrapings were directed back to the process.

The process temperature was measured using the Pt 1000 temperature probes placed inside the bioreactor. The process gas analysis was performed using the NANOSENS DP-28-MAP analyzer (NANOSENS, Tarnowo Podgórne, Poland) enabling the measurement of $\mathrm{O}_{2}( \pm 0.1 \%)$, $\mathrm{CO}_{2}( \pm 1 \%), \mathrm{CH}_{4}( \pm 1 \%), \mathrm{NH}_{3}( \pm 1 \mathrm{ppm})$ and $\mathrm{H}_{2} \mathrm{~S}$ $( \pm 1 \mathrm{ppm})$ content. This article describes the effect of biochar and different air-flow rates on the oxygen concentration in the free spaces between the treated wastes and in the process gases directed to the biofilter in terms of BD changes and AFP of treatment mixtures (with and without biochar addition). The concentration of individual gases was measured using 6 probes placed at different heights of the waste retention, and 2 probes in the gases entering the biofilter. The method of placing the probes in the waste was based on the results of studies by Malinowski (2017), who analyzed the temperature changes at different heights of waste retention in a BKB 100 type bioreactor during the aerobic biostabilization of UFMSW. The probes were periodically connected to the analyzer to measure the gas composition. The device indications in this area were averaged.

In addition, the changes in $\mathrm{BD}$ and $\mathrm{AFP}$ of treatment waste were described in this study. The samples from subsequent replicates were collected for analysis at the time of loading the bioreactors, and then after 21 days of the biostabilization process. Wet BD was measured based on the mass of known volume. AFP was determined using the following equation (Baptista et al., 2010; Malińska, and Zabochnicka-Świątek, M., 2013; Janczak et al., 2017):

$$
\begin{gathered}
\operatorname{AFP}(\%)= \\
=\left[1-B D\left(\frac{1-D M}{l_{w}}+\frac{D M \cdot O M}{l_{\text {OM }}}+\frac{D M(1-O M)}{l_{\text {ash }}}\right)\right] \cdot 100
\end{gathered}
$$

where: $A F P$ is the air-filled porosity (\%),

$B D$ is bulk density of waste,

$D M$ is the total solid content (wt\%),

$O M$ is the organic fraction content (\% d.m.) and

$l_{w}, l_{O M}$, and $l_{a s h}$ are the known density values of water, the $O M$, and the inorganic fraction (ash), respectively (Richard et al., 2002; Wójcik and Frączek, 2017).

\section{RESULTS AND DISCUSSION}

UFMSW is a mixture of wastes with grain sizes below $80 \mathrm{~mm}$, characterized by heterogeneous material composition (Wolny-Koładka et al., 2020). The waste composition was dominated by a fine fraction with a grain size below $10 \mathrm{~mm}$, and the average proportion of biodegradable waste (available for microorganisms) was greater than $40 \mathrm{wt} \%$ in each repetition. The differences between the proportions of biodegradable waste in UFMSW accepted in successive replicates were not statistically significant. The initial moisture content of UFMSW (without biochar) was $43.2 \pm 0.9 \mathrm{wt} \%$, while the organic matter (OM) content measured by loss on ignition was $47.9 \pm 0.8 \% \mathrm{~d} . \mathrm{m}$. The aforementioned indicators of waste meet the basic conditions for the biostabilization process (Jędrczak, 2008).

Figure 1 illustrates the average course of treated waste temperatures, depending on the adopted air-flow rate $\left[\mathrm{m}^{3} \cdot \mathrm{d}^{-1} \cdot \mathrm{kg} \mathrm{dm}\right.$.org $\left.{ }^{-1}\right]$. Thermophilic temperatures were obtained in all replicates, regardless of aeration size and biochar content. The maximum temperatures, i.e., $65^{\circ} \mathrm{C}$, were obtained mainly at the aeration intensities above $0.2 \mathrm{~m}^{3} \cdot \mathrm{d}^{-1} \cdot \mathrm{kg} \mathrm{dm} . \mathrm{org}^{-1}$. It is also significant that maximum temperature and thermophilic temperatures occurred in the air-flow rate replicates as the earliest: $0.4 \mathrm{~m}^{3} \cdot \mathrm{d}^{-1} \cdot \mathrm{kg} \mathrm{dm} . \mathrm{org}^{-1}$. In the experiments with the lowest air-flow rate $\left(0.1 \mathrm{~m}^{3} \cdot \mathrm{d}^{-}\right.$ $\left.{ }^{1} \mathrm{~kg} \mathrm{dm} . \mathrm{org}^{-1}\right)$, the achieved averaged maximum temperature below $60^{\circ} \mathrm{C}$ may indicate a lower enzymatic activity of microorganisms due to inefficient aeration of waste placed in the bioreactor. This may be the cause of the absence of final waste stabilization and slower moisture removal from the process (Czekała et al. 2015). After day 12 of the process, the temperature stabilized at about $20^{\circ} \mathrm{C}$ and did not increase until the end of the study. As shown in Fig. 1, the temperature changes during the MSW biostabilization process follow a pattern characteristic of waste biostabilization experiments conducted under laboratory conditions (Baran et al. 2016; Tom et al. 2016; Yuan et al. 2017; Malinowski et al. 2021).

Initial BD of UFMSW was $459.5 \mathrm{~kg} \mathrm{~m}^{-3}$ and was comparable to the values reported by Baran et al. (2016) and Malinowski et al. (2021). In terms of the added biochar proportion, the more biochar was added, the lower BD was achieved (Table 1). This change is not linear, due to the different 


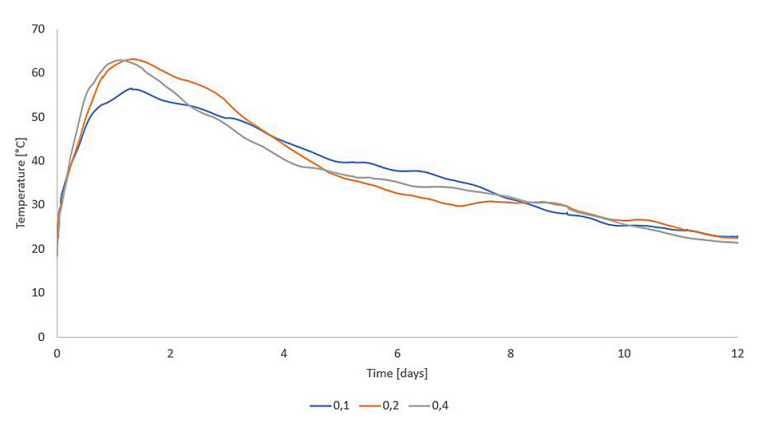

Fig. 1. Temperature changes in the bioreactor during biostabilization.

material composition of treated waste. The same relationship was also shown in their study for the composting process by Janczak et al. (2017). The $\mathrm{BD}$ of waste increased in each of the experiments conducted, with the increase depended mainly on the intensity of aeration. At the lowest air flow, a small amount of water was removed from the waste and as the volume decreased and the leachate was returned to the process, the density of the waste increased significantly (by $46.9 \mathrm{kgm}^{-3}$ on average). At aeration with an average air-flow rate of $0.4 \mathrm{~m}^{3} \cdot \mathrm{d}^{-1} \mathrm{~kg} \mathrm{dm}$.org ${ }^{-1}$, the increase in waste density was no longer as high (with $25.9 \mathrm{kgm}^{-3}$ on average), due to intensive water drainage, which was associated with a significant decrease in waste mass. Correlation analysis showed that as the aeration intensity increased, the value by which $\mathrm{BD}$ increased decreased statistically significantly $(\mathrm{r}=0.61)$.
The waste density, dry matter, and organic matter content allowed the calculation of the AFP of the treated waste. For UFMSW, an AFP value of about $60 \%$ guarantees the correct course of the biostabilization process and, in addition, this value usually increases with time (Malinowski et al. 2021). The AFP value for the analyzed UFMSWs was $66.9 \%$ and increased with the amount of biochar added (Table 1). As in the case of BD, these changes are not linear due to the heterogeneous material composition of treated waste. As a result of the process, the AFP value took both higher and lower values than the initial ones (Table 1). With increasing aeration intensity, there was generally an increase in AFP $(r=0.67)$, while the greater the addition of biochar, the smaller the change in the AFP values $(\mathrm{r}=-0.52)$.

Figure 2 shows the oxygen concentration in the treated waste as an average of the measurement locations, while Figure 3 shows the oxygen concentration in the waste gases directed to the biofilter. In each bioreactor, the initial oxygen concentration reached $20.7 \%$, which was identical with its content in the atmospheric air. A decrease in the amount of oxygen in the bioreactor chambers was observed over the course of the experiment, resulting from the oxygen consumption by aerobic microorganisms. Malinowski et al. (2019) reported that the biochar addition to the composting process under real condition effects increased the number of thermophilic bacteria in the first 14 days of the process. These bacteria

Table 1. Characteristics of bulk density and air-filled porosity before and after the biostabilization process of UFMSW without biochar (B0\%) and with biochar at five different doses (trials 2, 3, 4, 5 and 6)

\begin{tabular}{|c|c|c|c|c|c|c|c|}
\hline Parameters & Unit & Run 1 (B0\%) & Run 2 (B1.5\%) & Run 3 (B3\%) & Run 4 (B5\%) & $\begin{array}{c}\text { Run } 5 \\
\text { (B10\%) }\end{array}$ & $\begin{array}{c}\text { Run } 6 \\
\text { (B20\%) }\end{array}$ \\
\hline \multicolumn{8}{|c|}{ Air-flow rate: $0.1 \mathrm{~m}^{3} \cdot \mathrm{d}^{-1} \cdot \mathrm{kg} \mathrm{dm} . \mathrm{org}^{-1}$} \\
\hline BD - initial & \multirow{2}{*}{$\mathrm{kg} \cdot \mathrm{m}^{-3}$} & 459.5 & 444.0 & 420.9 & 410.1 & 399.1 & 383.2 \\
\hline$B D$ - final & & 499.2 & 483.9 & 457.8 & 442.4 & 475.5 & 422.9 \\
\hline AFP - initial & \multirow{2}{*}{$\%$} & 66.9 & 67.3 & 70.5 & 70.5 & 71.8 & 73.0 \\
\hline AFP - final & & 66.6 & 67.6 & 70.6 & 70.0 & 68.8 & 71.6 \\
\hline \multicolumn{8}{|c|}{ Air-flow rate: $0.2 \mathrm{~m}^{3} \cdot \mathrm{d}^{-1} \mathrm{~kg} \mathrm{dm} . \mathrm{org}^{-1}$} \\
\hline BD - initial & \multirow{2}{*}{$\mathrm{kg} \cdot \mathrm{m}^{-3}$} & 459.5 & 444.0 & 420.9 & 410.1 & 399.1 & 383.2 \\
\hline BD - final & & 487.2 & 480.1 & 453.8 & 443.0 & 432.9 & 421.5 \\
\hline AFP - initial & \multirow{2}{*}{$\%$} & 66.9 & 67.3 & 70.5 & 70.5 & 71.8 & 73.0 \\
\hline AFP - final & & 69.6 & 69.1 & 71.8 & 71.0 & 72.0 & 72.5 \\
\hline \multicolumn{8}{|c|}{ Air-flow rate: $0.4 \mathrm{~m}^{3} \cdot \mathrm{d}^{-1} \cdot \mathrm{kg} \mathrm{dm} . \mathrm{org}^{-1}$} \\
\hline BD - initial & \multirow{2}{*}{$\mathrm{kg} \cdot \mathrm{m}^{-3}$} & 459.5 & 444.0 & 420.9 & 410.1 & 399.1 & 383.2 \\
\hline$B D$ - final & & 484.4 & 474.4 & 440.9 & 430.2 & 424.4 & 417.4 \\
\hline AFP - initial & \multirow{2}{*}{$\%$} & 66.9 & 67.3 & 70.5 & 70.5 & 71.8 & 73.0 \\
\hline AFP - final & & 70.5 & 70.3 & 72.7 & 72.0 & 72.6 & 73.0 \\
\hline
\end{tabular}

BD - Bulk Density, AFP - Air-Filled Porosity 
consume the oxygen supplied to the process and can eventually lead to anaerobic conditions (Jedrczak 2008). Both air-flow rate and biochar addition determined significant changes in oxygen concentration.
a) Air-flow rate: $0.1 \mathrm{~m}^{3} \cdot \mathrm{d}^{-1} \mathrm{~kg} \mathrm{dm} . \mathrm{org}^{-1}$
b) Air-flow rate: $0.2 \mathrm{~m}^{3} \cdot \mathrm{d}^{-1} \mathrm{~kg} \mathrm{dm} . \mathrm{org}^{-1}$
c) Air-flow rate: $0.4 \mathrm{~m}^{3} \cdot \mathrm{d}^{-1} \mathrm{~kg} \mathrm{dm} . \mathrm{org}^{-1}$

The oxygen content of the free spaces in the waste decreased intensively during the first days of the process. This is characteristic of biological waste treatment processes (Czekała et al. 2015). The highest dynamics of changes in oxygen concentration were observed at an air-flow rate aeration of $0.4 \mathrm{~m}^{3} \cdot \mathrm{d}^{-1} \mathrm{~kg} \mathrm{dm} . \mathrm{org}^{-1}$. In this case, the changes in oxygen concentration were the fastest to occur, but the oxygen content of the waste did not decrease below $14 \%$. Moreover, the differences in the oxygen concentration between the sample without and with biochar addition were statistically significant (p-value $<0.05$ ) between hours 30 and 60 of the process. The results clearly show that the transfer of $\mathrm{O}_{2}$ into the bioreactor was always higher than the consumption by the microorganisms, as in the experiments conducted by Contreras-Cisneros et al. (2021). However, according to the guidelines set by Jędrczak (2008), aeration with a flow rate of $0.4 \mathrm{~m}^{3} \cdot \mathrm{d}^{-1} \mathrm{~kg} \mathrm{dm} . \mathrm{org}^{-1}$ should be considered optimal. The lowest oxygen concentration values were observed for biochar additives of $5 \%, 10 \%$ and $20 \%$. From day 10 of the process onwards, the oxygen concentration in the waste was maintained at over $19 \%$.

The use of a twice lower air-flow rate in almost all replicates (except for the 5\% addition of biochar) resulted in the oxygen concentration decreasing below 5\% between hours 24 and 80 of the process (Fig. 2). The differences in oxygen concentration at this time were not statistically significant (p-value < 0.05). Baran et al. (2016) observed that in the case of waste not supplemented with biochar in the aerobic biostabilization process, the oxygen concentration decreased below $4 \%$ between days 2 and 4 of the process. The oxygen content of $19 \%$ was only restored after 15 days of the process.

Oxygen concentration remained at low values the longest during the process using the lowest air-flow rate: $0.1 \mathrm{~m}^{3} \cdot \mathrm{d}^{-1} \mathrm{~kg} \mathrm{dm} . \mathrm{org}^{-1}$. With the addition of $10 \%$ and $20 \%$ biochar, it was found that between day 2 and 6 of the process, the oxygen concentration decreased to $0 \%$, which resulted in the development of anaerobic zones. Despite this, no methane $\left(\mathrm{CH}_{4}\right)$ emissions were found from the open spaces between the wastes. This was most likely affected by the laboratory scale of the experiment, the continuous feeding of air into the bioreactor and the short duration of the anaerobic zones. At the lowest air-flow rate, the differences in the waste oxygen concentration between samples $\mathrm{B} 0 \%, \mathrm{~B} 1.5 \%, \mathrm{~B} 3 \%$ and $\mathrm{B} 5 \%$ were not statistically significant.

The lack of oxygen in the treated waste may have been directly related to the increased microbial activity resulting from the large addition

a)

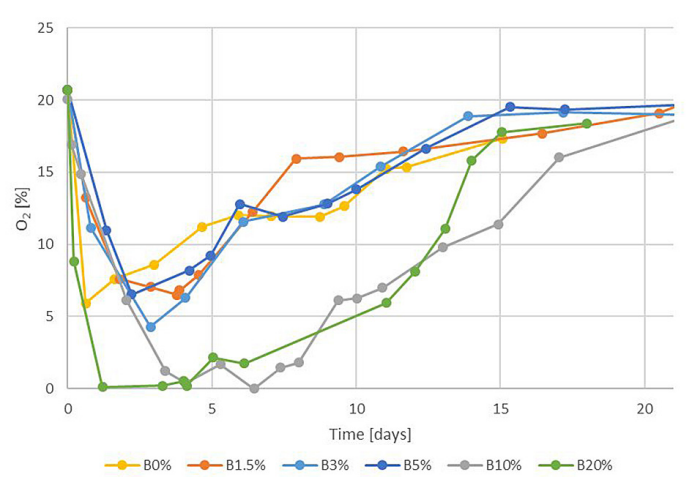

b)

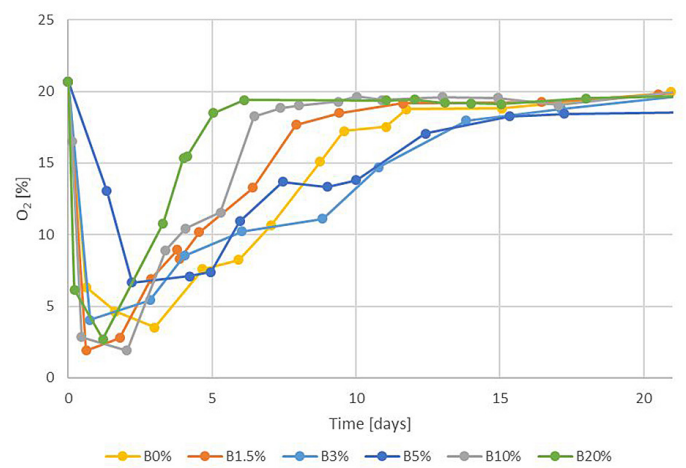

c)

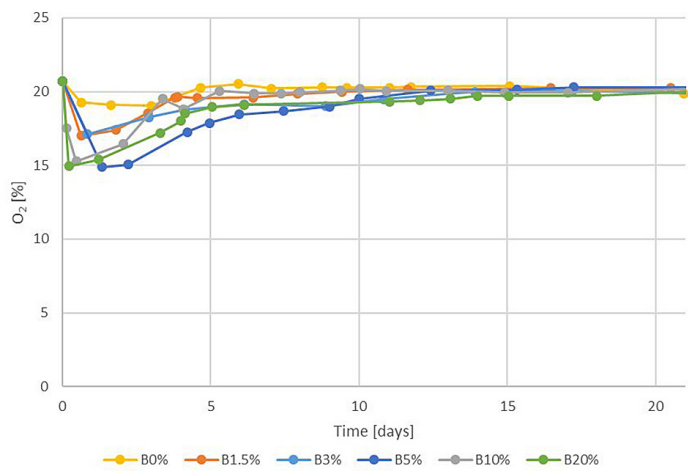

Fig. 2. $\mathrm{O}_{2}$ concentration in the free air spaces in waste treated in the bioreactor. 
of biochar. According to Lehmann and Joseph (2015), owing to its unique properties, biochar is a valuable source of mineral substances for microorganisms, including magnesium, calcium and carbonates. Additionally, due to the structure of biochar, its high porosity and ability to bind water molecules, it may also contribute to an increase in the abundance of microorganisms (Wei et al., 2014). It is worth noting that in the case of the addition of 10 and $20 \%$ biochar, there was simultaneously the greatest increase in BD and a significant decrease in AFP, generally indicating an abnormal process as a result of excessively high biochar addition and too low air-flow rate.

a) Air-flow rate: $0.1 \mathrm{~m}^{3} \cdot \mathrm{d}^{-1} \mathrm{~kg} \mathrm{dm} . \mathrm{org}^{-1}$
b) Air-flow rate: $0.2 \mathrm{~m}^{3} \cdot \mathrm{d}^{-1} \mathrm{~kg} \mathrm{dm} . \mathrm{org}^{-1}$
c) Air-flow rate: $0.4 \mathrm{~m}^{3} \cdot \mathrm{d}^{-1} \mathrm{~kg} \mathrm{dm} . \mathrm{org}^{-1}$

The oxygen concentration in the gases emitted from the biostabilization process (Fig. 3) was very similar to the oxygen content in the free spaces between the wastes. However, it is significant that in the case of the lowest air-flow rate value, a reduction of the time of oxygen absence (occurrence of anaerobic zones) in outlet air was observed for replicates with the addition of 10 and $20 \%$ biochar (between days 2 and 4 of the process). At air-flow rate of $0.2 \mathrm{~m}^{3} \cdot \mathrm{d}^{-1} \mathrm{~kg} \mathrm{dm} . \mathrm{org}^{-1}$ and with $10 \%$ biochar addition, zero oxygen concentration in the process exhaust gases was found at hour 76 of the process. No methane content was recorded in the air directed to the biofilter.

\section{CONCLUSIONS}

The following conclusions were formulated based on the obtained results:

1. With a high addition of biochar (more than $10 \%)$ and low aeration of waste $\left(0.1 \mathrm{~m}^{3} \cdot \mathrm{d}^{-1} \mathrm{~kg}\right.$ dm.org ${ }^{-1}$, complete oxygen consumption by the microorganisms involved in waste processing can occur during the intensive phase of the aerobic biostabilization process. This is associated with the formation of anaerobic zones.

2. The optimal air-flow rate for the aerobic biostabilization process is $0.4 \mathrm{~m}^{3} \cdot \mathrm{d}^{-1} \mathrm{~kg} \mathrm{dm} . \mathrm{org}^{-1}$, which allows the oxygen concentration greater than $14 \%$ to be maintained during the entire intensive phase of the biostabilization process, and also affects the increase in the AFP values, independently of the applied biochar addition.

3. No methane emissions were recorded, despite the presence of anaerobic zones during the intensive aerobic phase of biostabilization.

4. The results of these experiments extend the knowledge of the biochar effect on the aerobic biostabilization process, and provide an important report for practitioners.

\section{Acknowledgment}

This paper is the result of research project number 2017/01/X/ST10/01930 funded by the National Science Centre.

a)

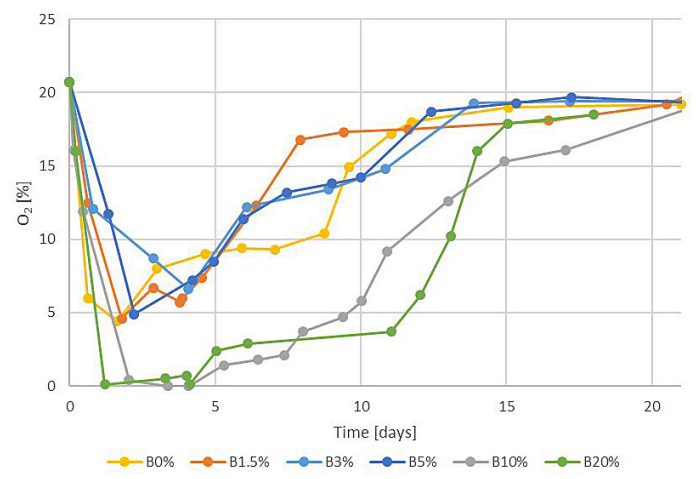

b)

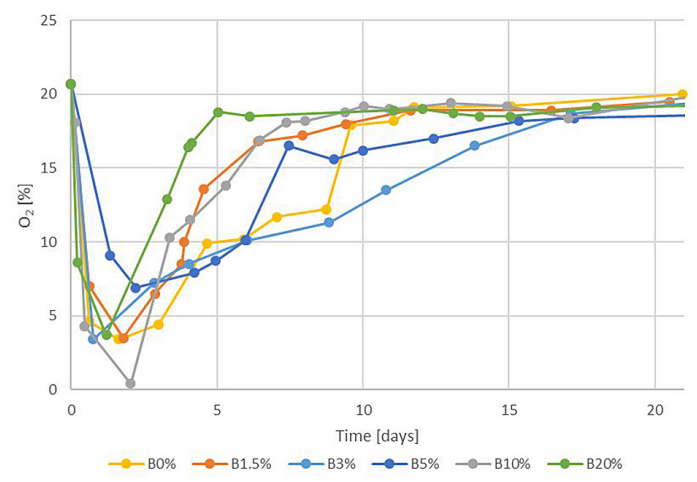

c)

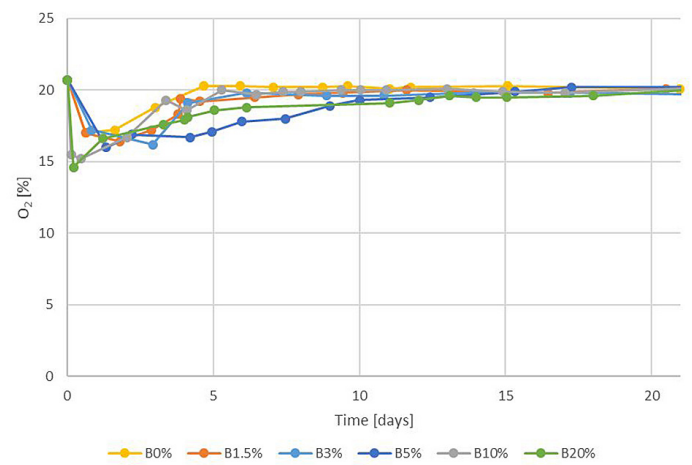

Fig. 3. $\mathrm{O}_{2}$ concentration in the outlet air (emitted gases) during biostabilization 


\section{REFERENCES}

1. Agyarko-Mintah E., Cowie A., Pal Singh B., Joseph S., Van Zwieten L., Cowie A., Harden S., Smillie R. 2017a. Biochar increases nitrogen retention and lowers greenhouse gas emissions when added to composting poultry litter. Waste Manage. 61, 138-149.

2. Agyarko-Mintah E., Cowie A., Van Zwieten L., Pal Singh B., Smillie R., Harden S., Fornasier F. 2017 b. Biochar lowers ammonia emission and improves nitrogen retention in poultry litter composting. Waste Manage. 61, 129-137.

3. Ahn H.K., Richard T.L., Glanville T.D. 2008. Laboratory determination of compost physical parameters for modeling of airflow characteristics. Waste Manage. 28 (3), 660-670.

4. Akdeniz N. 2019. A systematic review of biochar use in animal waste composting. Waste Manage. 88, 291-300.

5. Baran D., Famielec S., Koncewicz-Baran M., Malinowski M., Sobol Z. 2016. The changes in exhaust gas and selected waste properties during biostabilization process. Proc. ECOpole. 10 (1), 11-18.

6. BAT, 2018. Commission Implementing Decision (EU) 2018/1147 of 10 August 2018 establishing best available techniques (BAT) conclusions for waste treatment, under Directive 2010/75/EU of the European Parliament and of the Council. https://eur-lex. europa.eu/legal-content/EN/TXT/PDF/?uri=CELE $\mathrm{X}: 32018 \mathrm{D} 1147 \&$ from $=\mathrm{EN}$ (accessed: 17 October 2019).

7. Baptista M., Antunes F., Goncalves M.S., Morvan B., Silveira A. 2010. Composting kinetics in fullscale mechanical-biological treatment plants. Waste Manage. 30 (10), 1908-1921.

8. Białowiec A., 2018. Tlenowa biostabilizacja odpadów komunalnych. Obliczenia projektowe i eksploatacyjne. Wydawnictwo Uniwersytetu Przyrodniczego we Wrocławiu. (in Polish).

9. Contreras-Cisneros R.M., Orozco-Álvarez C., PiñaGuzmán A.B., Ballesteros-Vásquez L.C., MolinaEscobar L., Alcántara-García S.S., Robles-Martínez F. 2021. The Relationship of Moisture and Temperature to the Concentration of $\mathrm{O} 2$ and $\mathrm{CO} 2$ during Biodrying in Semi-Static Piles. Processes 9, 520.

10. Czekała W., Dach J., Malińska K., Przybył J., Myszura M. 2015. Dynamic of gaseous emissions during composting of sewage sludge with maize straw as a bulking agent. Journal of Ecological Engineering 16 (3), 108-114.

11. De Gisi S., Todaro F., Fedele G., Carella C., Notarnicola M. 2018. Alternating pure oxygen and air cycles for the biostabilization of unsorted fraction of municipal solid waste. Waste Manage. 79, 404-414.
12. den Boer E., Jędrczak A. 2017. Performance of mechanical biological treatment of residual municipal waste in Poland, in: Kaźmierczak, B., Kutyłowska, M., Piekarska, K., Jouhara H., Danielewicz A. (Eds.). International Conference on Advances in Energy Systems and Environmental Engineering (ASEE17). E3S Web of Conferences 22, 00020.

13. Dębicka M., Żygadło M., Latosińska J. 2017. The effectiveness of biodrying waste treatment in full scale reactor. Open Chem. 15, 67-74.

14. Dziedzic K., Łapczyńska-Kordon B., Malinowski M., Niemiec M., Sikora J. 2015. Impact of aerobic biostabilization and biodrying process of municipal solid waste on minimisation of waste deposited in landfills. Chem. Process Eng. 36 (4), 381-394.

15. Grzelka A., Miller U., Sówka I. 2018. The role for biological methods in the municipals management odour nuisance reduction strategy. Ecol. Chem. Eng. A. 25 (1), 51-60.

16. Grzesik K., Malinowski M. 2017. Life cycle Assessment of the mechanical - biological treatment of mixed municipal waste in Miki Recycling, Krakow, Poland. Environmental Engineering Science 34 (3), 207-220.

17. Godlewska P., Schmidt H.P., Ok Y.S., Oleszczuk P. 2017. Biochar for composting improvement and contaminants reduction. A review. Bioresour. Technol. 246, 193-202.

18. Jakubowski T. 2019. Empirical model of thermophilic phase of composting process. In: KrakowiakBal, A., Vaverková, M.D. (Eds.), Infrastructure and Environment. Springer, Cham, pp. 129-135.

19. Janczak D., Malińska K., Czekała W., Cáceres R., Lewicki A., Dach J. 2017. Biochar to reduce ammonia emissions in gaseous and liquid phase during composting of poultry manure with wheat straw. Waste Manage. 66, 36-45.

20. Jędrczak, A., 2008. Biologiczne przetwarzanie odpadów (Biological Waste Treatment). PWN, Warszawa. (in Polish).

21. Jędrczak A., Suchowska-Kisielewicz M. 2018. A comparison of waste stability indices for mechanical-biological waste treatment and composting plant. Int. J. Environ. Res. Public Health. 15, 2585.

22. Kasiński S., Slota M., Markowski M., Kamińska A. 2016. Municipal solid waste stabilization in a reactorwith an integrated active and passive aeration system. Waste Manage. 50, 31-38.

23. Khan N., Clark I., Sánchez-Monedero M.A., Shea S., Meier S., Bolan N. 2014. Maturity indices in co-composting of chicken manure and sawdust with biochar. Bioresour. Technol. 168, 245-251.

24. Knapczyk A., Francik S., Frączek J., Ślipek Z. 2019. Analysis of research trends in production of solid biofulels. Engineering for Rural Development. 18. 
1503-1509.

25. Lehmann J., Joseph S. 2015. Biochar for Environmental Management. Science, Technology and Implementation, second ed., p. 944. ISBN-13: 978-0415704151.

26. Malinowski M. 2017. Analysis of the undersize fraction temperature changes during the biostabilization process. Infrastruct. Ecol. Rural Areas. IV (3), 1773-1784.

27. Malinowski M.,Wolny-Koładka K., Vaverková M.D. 2019. Effect of biochar addition on the OFMSW composting process under real conditions. Waste Manage. 84, 364-372.

28. Malinowski M., Famielec S., Wolny-Koładka K., Sikora J., Gliniak M., Baran D., Sobol Z., Salamon J. 2021. Impact of digestate addition on the biostabilization of undersized fraction from municipal solid waste. Science of The Total Environment. 770: 145375.

29. Malińska K., Zabochnicka-Świątek M. 2013. Selection of bulking agents for composting of sewage sludge. Environ. Prot. Eng. 39 (2), 91-103.

30. Maxianová A., Vaverková M.D. 2021. Optimization of a food waste composting process with a sawdust. International Journal od Sustainable Agricultural Management and Informatics. 6 (4), 319.

31. Michel F., Recchia J., Rigot J., Keener H. 2004. Mass and nutrient loss during the composting of dairy manure amended with sawdust or straw. Compos. Sci. Utilization. 12, 332-334.

32. Neugebauer M., Jakubowski T., Sołowiej P., Wesołowski M. 2018. A Fuzzy Model of the Composting Process with Simultaneous Heat Recovery and Aeration Rate Control. In: Mudryk K., Werle S. (eds) Renewable Energy Sources: Engineering, Technology, Innovation. Springer Proceedings in Energy. Springer, Cham.

33. Neugebauer M., Sołowiej P. 2017. The use of green waste to overcome the difficulty in small-scale composting of organic household waste. Journal of Cleaner Production 156, 865-875.

34. Pawnuk M., Grzelka A., Miller U., Sówka I. 2020. Prevention and Reduction of Odour Nuisance in Waste Management in the context of the Current Legal and Technological Solutions. Journal of Ecological Engineering 21 (7), 34-41.

35. Puyuelo B., Gea T., Sanchez A. 2014. GHG emissions during the high-rate production of compost using standard and advanced aeration strategies. Chemosphere, 109, 64-70.

36. Richard T.L., Hamelers H., Veeken A., Silva T., 2002. Moisture relationships inccomposting processes. Compost Sci. Util. 10 (4), 286-302.

37. Scaglia B., Orzi V., Artola A., Font X., Sánchez
A., Adani F. 2011. Odours and volatile organic compounds emitted from municipal solid waste at different stage of decomposition and relationship with biological stability. Bioresour. Technol. 102, 4638-4645.

38. Soboniak E., Bień J.D. 2015. Proces mechaniczno-biologicznego przetwarzania zmieszanych odpadów komunalnych wedle nowych przepisów w instalacji Regionalnego Zakładu Zagospodarowania Odpadów w Sobuczynie. Inżynieria i Ochrona Środowiska 18 (4), 483-495.

39. Stejskal B., Malsová A., Báreková A., 2017. Comparison of family house and apartment households bio-waste production and composition. Waste Forum 4, 237-243.

40. Tom A., Pawels R., Haridas A. 2016. Biodrying process: a sustainable technology for treatment of municipal solid waste with high moisture content. Waste Manage. 49, 64-71.

41. Vaverková M.D., Elbl J., Voběrková S., Koda E., Adamcová D., Gusiatin Z.M., Rahman A.A., Radziemska M., Mazur Z. 2020. Composting versus mechanical-biological treatment: does it really make a difference in the final product parameters and maturity. Waste Manage. 106, 173-183.

42. Velis C.A., Longhurst P.J., Drew G.H., Smith R., Pollard S.J.T. 2009. Biodrying for mechanical-biological treatment of wastes: a review of process science and engineering. Bioresour. Technol. 100, 2747-2761.

43. Voytovych I., Malovanyy M., Zhuk V., Mukha O. 2020. Facilities and problems of processing organic wastes by family-type biogas plants in Ukraine. Journal of Water and Land Development 45, 185-189.

44. Wei L., Shutao W., Jin Z., Tong X. 2014. Biochar influences the microbial community structure during tomato stalk composting with chicken manure. Bioresour. Technol. 154, 148-154.

45. Wierzbińska M. 2021. The Application of Mineral Sorbents to remove Volatile Organic Compound from the Gases Emitted from the Composting Process. Journal of Ecological Engineering. 22 (2), 98-110.

46. Wócik A., Frączek J. 2017. The influence of the repose angle and porosity of granular plant materials on the angle of internal friction and cohesion. Tribologia 5, 117-123.

47. Wolny-Koładka K., Malinowski M., Żukowski W. 2020. Impact of calcium oxide on hygienization and self-heating prevention of biologically contaminated polymer materials. Materials 13, 4012.

48. Yuan J., Zhang D., Li Y., Chadwick D., Li G., Li Y., Du L. 2017. Effects of adding bulking agents on biostabilization and drying of municipal solid waste. Waste Manage. 62, 52-60. 